\title{
O Reino do Ndongo no Contexto da Restauração: Mbundus, Portugueses e Holandeses na África Centro Ocidental
}

\author{
Flávia Maria de Carvalho ${ }^{1}$
}

\section{Resumo:}

O principal objetivo do artigo é analisar as relações estabelecidas entre os governadores e funcionários da Coroa portuguesa e as autoridades locais do reino do Ndongo, no período de 1640 (Restauração portuguesa) a 1671 (fim da autonomia política da região). O período foi marcado por uma série de conflitos como as invasões holandesas nos territórios que posteriormente passaram a ser chamados de Angola, e embates travados entre religiosos da Companhia de Jesus e capuchinhos italianos que contestavam o monopólio do missionarismo português na África Centro Ocidental.

Palavras-chaves: História de Angola, reino do Ndongo, elites políticas africanas, administração portuguesa.

\begin{abstract}
:
The main purpose of this paper is to analyze the relations between governors and officials of the Portuguese Crown and local authorities of the kingdom of Ndongo, between 1640 (Restoration of Portugal) to 1671 (end of the political autonomy of its region). The period was marked by a series of conflicts as the Dutch invasion in the territories that later came to be called Angola, and clashes between religious caught the Society of Jesus and Italian Capuchin who were contesting the monopoly of Portuguese missionarism in Western Central Africa.
\end{abstract}

Key-words: History of Angola, the kingdom of Ndongo, African political elites, Portuguese administration.

\section{Apresentação}

A partir da década de quarenta do século XVII o então reino do Ndongo passa a ser o cenário de importantes embates internacionais. Em um primeiro plano os colonizadores portugueses, estabelecidos nos territórios da África Centro Ocidental desde finais do século XV, são desafiados por invasores holandeses que tinham pretensões nítidas, e até mesmo óbvias, de tomar o controle do fornecimento de escravos. O momento também é o cenário da Restauração portuguesa ${ }^{2}$, marcando a retomada da soberania política portuguesa e a ascensão da Casa de Bragança sobre o reino e sobre suas possessões coloniais.

Simultaneamente, a Coroa portuguesa e o Vaticano entram em embates sobre o controle das atividades missionárias. Conflitos protagonizados por inacianos portugueses e capuchinhos italianos, que não concordavam com o monopólio lusitano da evangelização.

\footnotetext{
${ }^{1}$ Doutoranda em História da Universidade Federal Fluminense desenvolve pesquisas sobre as relações entre os governadores e demais funcionários da Coroa portuguesa e as elites políticas de Angola nos séculos XVII e XVIII, com projeto intitulado "Elites política angolanas: ngolas, sobas, macotas, macunzes e tandalas na dinâmica dos governos portugueses séculos XVII e XVIII", orientado pela Prof a ${ }^{a}{ }^{a}$ Mariza de Carvalho Soares. Mestre em História pela mesma instituição, com dissertação intitulada "Violência e corpo escravo: impasses nas experiências coloniais ilustradas - Rio de Janeiro e Angola na segunda metade do século XVIII", orientada pelo Prof. Dr. Luciano Raposo de Almeida Figueiredo.

2 Adotamos como referências principais para as análises sobre a Restauração portuguesa os trabalhos de Eduardo D’Oliveira França. Portugal na época da restauração. São Paulo: Hucitec, 1997; e de Fernando Bouza Álvarez. Portugal no tempo dos Filipes. Política, cultura, representações. (1580-1668). Lisboa: Edições Cosmos, 2000.
} 
Internamente a situação dos portugueses também não era estável. Intrigas e guerras marcam esse período da presença portuguesa nos territórios dos povos mbundus, em contraponto com o discurso vigente no período anterior da União Ibérica, onde as instruções filipinas defendiam relações pacíficas entre colonizadores e as lideranças locais. Sustentados pelo discurso missionário, os agentes da Coroa deveriam resgatar almas, ao mesmo tempo em que os corpos deveriam ser vendidos nos mercados americanos. O período posterior da Restauração portuguesa marca a redefinição de estratégias junto as principais lideranças locais, período de guerras e de grande violência principalmente nos governos de Salvador Correia de Sá, João Fernandes e André Vidal de Negreiros, período dos governos brasílicos em Angola.

Nesse contexto uma das principais prioridades entre os administradores portugueses era a meta de legitimar seu poder frente às ameaças internas e externas que fragilizavam o seu governo e seus objetivos nas regiões do reino de Ndongo, que no ano de 1671 perde sua autonomia, sucumbindo aos interesses metropolitanos, e passando a ser denominado Angola.

Em síntese, o recorte cronológico adotado mostra os desafios assumidos pelos portugueses para legitimar sua soberania nos territórios da África Centro Ocidental, mais especificamente no reino do Ndongo, terra do povo mbundu.

Dividimos o trabalho em três partes:

$1^{\text {a }} \mathrm{O}$ reino do Ndongo: a corte africana do Ngola entre os mbundus;

$2^{\mathrm{a}} \mathrm{O}$ Ndongo e as disputas internacionais;

$3^{a}$ Angola brasílica: os governos de Salvador Correia de Sá, André Vidal de Negreiros e João Fernandes.

\section{$1^{a}$ parte: $\mathrm{O}$ reino do Ndongo: a corte africana do Ngola entre os mbundus}

\subsection{Territorialidade e identidade mbundu}

Os territórios do então chamado reino do Ndongo compreendiam faixas de terra entre dois importantes rios da região: o Kwanza e o Bengo. Cercado por importantes reinos da África Centro Ocidental como o Congo e a Matamba, o Ndongo era habitado pelos mbundus $^{3}$, povo de origem banto, falante de kimbundu, que segundo Jan Vansina teria migrado para a região buscando áreas com melhores potenciais agrícolas ${ }^{4}$.

\footnotetext{
${ }^{3}$ A região era habitada majoritariamente pelo povo mbundu, também chamado e grafado em alguns textos e fontes como umbundu.

${ }^{4}$ VANSINA, Jan. Paths in the Rainforests. Toward a History of Political Tradition in Equatorial Africa. Madison. Wisconsin, 1990.
} 
A principal autoridade entre os mbundus era o $\mathrm{Ngola}^{5}$, título que deu origem a designação portuguesa Angola para suas conquistas. Contudo o poder do Ngola era restrito e limitado. Muitos dos sobas que viviam em seus domínios eram totalmente independentes, ou por razões geográficas que dificultavam o acesso a esses sobados, ou pela ausência de legitimidade do poder político do Ngola junto a esses chefes locais. Alguns sobas reconheciam o Ngola somente por seus poderes místicos, como por exemplo, em relação ao dom de fazer a chuva ${ }^{6}$, mas não o viam como autoridade política.

O sistema político e administrativo do reino do Ndongo nesse período era diferente do modelo vigente no reino do Congo, como esclarece Birmingham:

\begin{abstract}
Contrariamente ao Congo, onde, por exemplo, um mani Mbata era governador da província de Mbata, um mani Mbamba governador da província de Mbamba e assim por diante, no Ndongo não havia governadores de províncias. [...] Cada uma dessas regiões dividia-se em numerosos chefados (sobados), na sua maioria autônomos?
\end{abstract}

Essa diferença organizacional entre Congo e Ndongo foi determinante para a definição da meta dos portugueses na região. Seria mais vantajoso concentrar os esforços para a contestação da soberania do Ngola do Ndongo junto aos seus sobas, do que do Mani Congo junto aos manis provinciais.

A presença dos portugueses na região, e seu relacionamento com os mbundus, implicaram na necessidade da decodificação de símbolos e procedimentos relacionados ao exercício do poder, itens totalmente desconhecidos pelos pioneiros, mas que aos poucos foram se tornando familiares aos sucessores da empreitada africana nos territórios do Ndongo.

O historiador Luiz Felipe Barreto ${ }^{8}$ analisou essa questão de forma genérica em seus estudos sobre as etapas multisseculares do processo de colonização português. A contribuição salienta como um imperativo do aprendizado da realidade colonial para a definição de estratégias e de metas específicas para cada região do ultramar português.

Os descobrimentos antropológicos seriam produtos da aquisição de informações e da compreensão dessas linguagens e simbolismos variados sobe os modelos de organização e

\footnotetext{
${ }^{5}$ HEINTZE, Beatrix. Angola nos séculos XVI e XVII. Estudos sobre fontes, métodos e História. Luanda: Ministério da Cultura, 2007. De acordo com a historiadora, outra terminologia utilizada para o título dos reis do Ndongo era Kiluanji.

${ }^{6}$ Era comum os sobas enviarem pagamentos para o Ngola em troca de chuvas. Era responsabilidade dos sobas fazerem com que esses tributos chegassem às mãos do Ngola, não existiam cobradores de impostos na corte do Ngola. HEINTZE, Beatrix. Op cit.

${ }^{7}$ BIRMINGHAM, David. Alianças e conflitos. Os primórdios da ocupação estrangeira em Angola (1483-1750). Luanda: Arquivo Histórico de Angola, 2004.

8 BARRETO, Luiz Felipe. Os Descobrimentos e ordem do saber - uma análise sócio cultural. Lisboa: Ed. Gradiva, 1989. Luiz Felipe Barreto não analisa casos específicos da colonização portuguesa, mas insere a noção das "Descobertas Antropológicas" para a compreensão da presença portuguesa nos territórios ultramarinos portugueses.
} 
identificação de hierarquias e dos canais de comunicação úteis na construção de uma relação entre colonizadores e as autoridades locais.

A ocupação portuguesa na região, iniciada no século XV, forneceu esses prérequisitos aos agentes colonizadores, o que fez com que no século XVII, em comparação com seus rivais estrangeiros, os portugueses levassem vantagens em alguns itens. Essa bagagem cultural favoreceu os deslocamentos dos lusitanos pelo interior, a comunicação com pombeiros e tangomaos ${ }^{9}$, assim como a compreensão de terminologias linguísticas kimbundus, porém não bastou para que posteriores alianças entre os mbundus e estrangeiros fossem evitadas, quando estes sinalizavam com vantagens comerciais no trato negreiro.

Do estabelecimento de feitorias, passando pela adoção do sistema de capitanias hereditárias efetivado por Paulo Dias Novais ${ }^{10}$, até os investimentos militares para a subordinação do reino do Ndongo, os portugueses experimentaram métodos diversificados na tentativa de tornar Angola uma peça funcional em seu sistema colonial.

O sistema de capitanias foi implementado por uma Carta Régia no ano de 1571, definia os limites dos territórios localizados nas margens do rio Kwanza. De acordo com essa Carta Régia essa capitania deveria ser dividida em duas partes: uma moldada nos moldes tradicionais das capitanias implementadas na América Portuguesa, outra parte que deveria ser posteriormente devolvida à Coroa portuguesa. Após a morte de Paulo Dias Novais, várias tensões passaram a tomar conta dos territórios de Angola motivadas pelas disputas de sucessão, esses desentendimentos passaram a ser uma preocupação para os colonizadores, o que levou a Coroa anular o sistema de capitanias e implementar o sistema de governo-geral no ano de 1592, e no ano de 1595 foi criado o asiento - privilégio de fornecimento de escravos por parte dos traficantes portugueses para os mercados da América Espanhola ${ }^{11}$.

A instrução da Coroa portuguesa que estava voltada para a redução do poder do Ngola tinha propósito claro: ampliar as áreas de fornecimento de escravos para o crescente

\footnotetext{
9 ZERON, Carlos Alberto. "Pombeiros e Tangomaos, intermediários do tráfico de escravos na África - século XVI". In: II Colóquio Internacional sobre mediadores culturais. Lagos: Centro de Estudos Gil Eanes, 1999, p. 15-38. Segundo o historiador a grafia da palavra pumbeiro se aproxima do termo do dialeto africano kimbundo "pumbu", da mesma forma que "mpunbu", que significam originalmente três pontos comerciais, relacionados aos grandes mercados da África Centro Ocidental.

${ }^{10} \mathrm{O}$ sistema de capitanias foi implementado no ano de 1571 através de uma Carta Régia do mesmo ano.

11 O trabalho de Maria de Fátima Gouvêa fornece um importante mapeamento do quadro administrativo das heterogêneas possessões do Império Ultramarino Português, analisando o papel dos privilégios e das redes clientelares na formação desses quadros burocráticos. GOUVÊA, Maria de Fátima. "Poder Político e Administração na Formação do Complexo Atlântico Português (1645-1808)". In: FRAGOSO, João; BICALHO, Maria Fernanda; GOUVÊA, Maria de Fátima (Orgs.). O Antigo Regime nos trópicos: a dinâmica imperial portuguesa. Rio de Janeiro: Civilização Brasileira, 2001, p. 285-315.
} 
mercado atlântico de meados do século XVII, além de assegurar uma importante aliança previamente defensiva às possíveis, e anunciadas, invasões holandesas na África Centro Ocidental.

Os Ngolas tinham seu poder marcado pelo sobrenatural, seriam os grandes responsáveis por trazer a chuva. Sua função era estratégica para a manutenção da unidade do reino, mesmo quando para muitos sobas essa vertente mística era a única reconhecida. Para os mbundus o controle da natureza era uma atribuição do Ngola, relacionando essa prática ao dom de comunicação com os ancestrais, elemento estranho aos colonizadores portugueses, que precisaram de tempo para compreender a forte presença da ancestralidade e do componente mágico da figura real no processo de reconhecimento de seu soberano.

As hipóteses explicativas sobre as origens do primeiro Ngola foram analisadas por Miller $^{12}$. De acordo com seus estudos o primeiro Ngola não teria sido uma pessoa concreta, mas sim "o princípio abstrato da organização política baseada no Ngola", que originalmente teria constituído um emblema de linhagem em forma de um pedaço de ferro.

Um componente cultural marcante do povo mbundu foi a valorização das tradições, e a força da oralidade na preservação de valores e crenças. Graças a isso, a tradição do rei ferreiro foi preservada em várias regiões da África Centro Ocidental, ponto que pode ser percebido também no uso de insígnias comuns em diferentes regiões.

Frente a isso os portugueses constataram a função múltipla do Ngola, que, portanto deveria ser mantido no poder, desde que fosse um aliado português. Esse objetivo foi conquistado no ano de 1626, quando auxiliado pelos portugueses assumiu o título máximo do Ndongo, Ngola Ari $^{13}$, que se manteve durante toda sua vida um aliado incondicional dos portugueses.

\subsection{A bierarquia do Ndongo em meados do século XVII}

O reino do Ndongo era formado por uma sociedade altamente hierarquizada, onde papéis eram muito bem definidos, e a prestação de serviços ao Ngola levou à formação de uma complexa corte.

Além do Ngola e dos sobas, existiu no Ndongo um grupo extremamente poderoso: os makotas. Esses eram homens descritos como idosos, que exerciam a função de

\footnotetext{
${ }^{12}$ MILLER, Joseph C. Poder político e parentesco. Os antigos Estados mbundus em Angola. Luanda: Ministério da Cultura, 1995.

${ }^{13}$ Ngola Ari auxiliou em vários momentos os portugueses, entre seus feitos exemplificamos a vitória dos portugueses auxiliados por suas tropas, na vitória sobre a rainha Nzinga, entre 1626 e 1627. BIRMINGHAM, David. Op cit. HEINTZE, Beatrix. Op cit.
} 
aconselhar o Ngola. Sua influência era tamanha que chegava a limitar o poder dos sobas e até mesmo a interferir nos processos de sucessão dos Ngolas.

A sucessão real entre os mbundus deveria seguir os princípios baseados na matrilinearidade, válido na poligâmica sociedade do Ndongo. De acordo com os relatos de Cadornega ${ }^{14}$ o sucessor do Ngola deveria ser filho da esposa principal do rei, caso esta não tivesse filhos, o herdeiro deveria ser o filho da segunda esposa. Os filhos do rei com escravas não tinham direito a pleitear o cargo, princípio válido também para as sucessões entre os sobas. O que Cadornega nos mostra é o papel decisivo dos makotas no processo sucessório.

Através da análise entre velhice e conhecimento identificamos a valorização da experiência de vida, além do peso da oralidade na divulgação e preservação ancestral desses aconselhamentos entre a cultura mbundu.

De acordo com Beatrix Heintze ${ }^{15}$ a hierarquia dos mbundus era formada por vários outros grupos. Abaixo dos Ngolas e dos makotas, estavam os sacerdotes supremos chamados mani-ndongos, abaixo vinham os tandalas, espécie de primeiros ministros, em seguida os tandalas de cari, ministros secundários, na sequência vinham as lideranças militares representadas pelos ngolambole, que eram os chefes dos exércitos, depois os ferreiros, grupo também ligado aos poderes sobrenaturais em função da relação entre a origem do Ngola e o mito do rei ferreiro, e as especializações funcionais do séquito do Ngola: o criado (mordomo): mwene lumbu, o roupeiro: mwene musete, o chefe de cozinha: mwene quizoula e os embaixadores que representavam a autoridade real nos acordos que exigiam deslocamentos: os macunzes ${ }^{16}$.

A estratificação social entre os mbundus também é comprovada pela existência de grupos que poderiam ser escravizados e de outros que não poderiam. $\mathrm{Na}$ língua kimbundu, os murindas eram pessoas que não poderiam perder sua liberdade, evidenciando os privilégios e as desigualdades nos estatutos sociais.

As terminologias podem variar quando as fontes são confrontadas, como o que ocorre na análise do Diário anônimo de uma viagem às costas d'África e as Índias espanholas ${ }^{17}$.

\footnotetext{
${ }^{14}$ A obra de Cadornega é uma das mais importantes fontes para a história da presença portuguesa em Angola. Descrevendo com detalhes muitos hábitos e feitos da colonização angolana, Cadornega é sem dúvida uma referência essencial para os estudos africanistas. CADORNEGA, Antônio de Oliveira. História Geral das Guerras Angolanas. Lisboa: Divisões de Publicações e Biblioteca, 1942.

${ }^{15}$ HEINTZE, Beatrix. Op cit.

${ }^{16}$ Idem.

17 "Diário anônimo de uma viagem às Costas d'África e às Índias Espanholas". Organizado e comentado por Gilberto Ferrez. In: Revista do Instituto Histórico e Geográfico Brasileiro, vol. 267, abril-junho de 1965. Esse manuscrito tem como título original: Journal d'un vouyage sur lês costes d'afrique et aux Indes d'Espagne avec une description particulière de la rivière de la Plate, de Buenosayres, e autres lieux; commencé en 1702 et fini en 1706, editada em
} 
Trabalhando com esse fascinante relato nos deparamos com outros termos para a designação do séquito do Ngola.

O documento, transcrito na Revista do IHGB e editado junto a um comentário de Gilberto Ferrez, descreve a incrível trajetória de um "espião" anônimo enviado à África para fiscalizar, e reportar, para um "amigo" em Paris todas as etapas do tráfico. O objetivo de sua viagem era obter escravos na costa africana e transportá-los para Buenos Aires. A embarcação cedida pelo rei francês à Compagnie Royale de l'Assiente saiu das regiões de La Rochelle no ano de 1702 e partiu em direção as terras de Loango e posteriormente de Cabinda.

Ao chegar às terras de Cabinda o espião se deparou com quatro embarcações: uma holandesa, duas portuguesas e uma inglesa. Essa afirmação nos mostra a abertura internacional do tráfico na costa Centro Ocidental no início do século XVIII, e a dificuldade encontrada pela Coroa portuguesa para estabelecer um controle efetivo sobre o fornecimento de escravos para Europa e para as colônias.

Os trechos mais ricos do documento são os que descrevem os procedimentos necessários para se estabelecer os contatos iniciais com o principal soba das terras de Cabinda. Assim como em outros relatos, a moradia do soba é descrita como um local isolado, que exigia um deslocamento aproximado de quatro léguas em relação à costa.

David Birmingham ${ }^{18}$ mostra que o isolamento dos Ngolas era um comportamento comum. Os reis permaneciam em suas propriedades mantendo contatos restritos somente com alguns de seus funcionários, que eram incumbidos de representá-los junto aos estrangeiros interessados em estabelecer alianças e obter a permissão prévia para a instalação dos barracões no litoral. Esse hábito do Ngola reforça o caráter místico da autoridade do chefe mbundu, ao mesmo tempo em que descentralizava o poder decisório do Ngola, já que suas ordens eram transmitidas por terceiros, em função da opção pela ausência de contatos com os colonizadores e demais autoridades locais que por ventura necessitassem estabelecer acordos e alianças.

\footnotetext{
Amsterdã em 1723. Na Biblioteca Nacional existe outra edição dessa fonte rara, que foi trabalhada por Affonso d'Escragnolle Taunay, que utilizou o Diário em seus trabalhos Na Babia Colonial 1610-1764 e Rio de Janeiro de antanho, no capítulo Oficial negreiro publicado pela RIHGB, no tomo 90, vol. 144. Taunay também utilizou a preciosa fonte em seu clássico Subsídios para a História do tráfico africano no Brasil Colonial. A versão lida por Taunay foi editada na mesma cidade, só que sua data de edição varia para 1730. Além dele Regine Pernous fez um estudo sobre esse documento que foi publicado com o título "L'Amerique du Sud au XVIII siécle" no Cabiers d'Histoire et de Bibliographie $\mathrm{n}^{\circ}$ 3, Nantes, 1943. Para esse trabalho a pesquisadora teve acesso à outra edição do manuscrito também datada de 1723 e editada em Rouen.

${ }^{18}$ BIRMINGHAN, David. Op cit.
} 
No já citado Diário anônimo o rei é designado como $A n g o y e^{19}$, e o chefe responsável pelo comércio como mafongne que acompanhado por um capitão português deveria conduzir os franceses até o rei Angoye. Nas palavras do viajante anônimo:

Entraram então para ver o rei do país. O rei Angoye residia a quatro léguas de Cabinda, e recebeu-nos no dia 21. Para isso enviaram uma embaixada que foi levada por um capitão português e o Mafougne, ou chefe do comércio; aguardava-os em terra com redes e negros que deveriam conduzi-los até o rei. A duas léguas dali, encontraram vários oficiais e guardas que o rei enviara para recebê-los. Todos incorporados chegaram ao palácio (se tal nome se pode dar a uma cabana feita de bambus e coberta de palha). Graças a oferta de magníficos presentes, um manto escarlate, um robe-de-chambre e um chapéu com penacho de plumas brancas, o rei prometeu ajudá-los a obter os negros que precisava. Tiveram também licença para construir uma feitoria ou barracão para depósito das mercadorias trazidas da Europa, com que deveriam adquirir os 500 negros que pretendiam levar; isso requeria tempo, muita diplomacia, sagacidade e paciência, presentes e uma série de complementos ${ }^{20}$.

Nas palavras do anônimo "nunca se despede sem antes beber. Por isso é preciso trazer algumas garrafas de cachaça, que é a alma da conversa e sem o que seria bem difícil chegar a algum acordo com os negros" ${ }^{21}$.

Nas páginas do Diário surgem outros cargos dos africanos que compunham esse cenário de trocas variadas. O rei tinha secretários e conselheiros, sendo que alguns falavam até português. Entre eles os destacados pelo autor foram: o mambuc, que era o primeiro ministro e sucessor do rei; o maure, que era o segundo ministro e chefe do Conselho, e o macinge, que era o capitão da costa, que além de outras funções abastecia os navios negreiros.

Entre os intermediários do tráfico destacamos os pumbeiros e os tangomaos ${ }^{22}$. Os pumbeiros representavam os interesses portugueses nos negócios do tráfico, eram os agentes "legais" da operação, enquanto os tangomaos eram os atravessadores que negociavam escravos sem a permissão da Coroa portuguesa, que desde o século XVII já havia instaurado regulamento para o controle das atividades de resgate, venda e transporte dos africanos. Os tangomaos em contrapartida eram mais integrados às comunidades com que mantinham relações, passando a ter um vínculo maior com os hábitos e as formas de viver dos africanos. Outra diferença entre os dois grupos era a forma com que eles se inseriam nos grupos locais. Os pumbeiros se aproximavam das populações africanas com o interesse definido voltado para obtenção de informações sobre quais seriam as melhores possibilidades de trocas para a aquisição dos cativos.

\footnotetext{
${ }_{19}$ Precisamos estar atentos quanto à utilização literal desses termos, já que temos a noção de que eles foram transcritos por um francês, a partir do que ele ouvia nas terras de falantes de kimbundu.

${ }^{20}$ FERREZ, Gilberto (org.). "Diário anônimo...". Op cit

21 Idem. Identificação de determinados itens valorizados nas etapas que garantiam o contato com as autoridades nativas.

22 ZERON, Carlos Alberto. Op cit.
} 
Essa aproximação dos tangomaos, ou lançados, com a cultura africana foi comentada pelo jesuíta J. Tavares, que vivia em Angola mostrando como a lógica do tráfico repercutiu em variados procedimentos comportamentais, alterando até mesmo suas características:

\begin{abstract}
Vestindo-se como nativos, entalhando no rosto as marcas das etnias locais, os lançados foram os primeiros europeus a se adaptarem aos trópicos. Andam nus e para mais se acomodarem, e com o natural usarem o gentio da terra onde tratam, riscam o corpo todo com um ferro [...] e fazendo nele muitos lavores [...] que ficam parecendo em várias figuras, como de lagostas, serpentes [...] andam por todo aquele Guiné tratando e comprando escravos por qualquer título que os pode haver ${ }^{23}$
\end{abstract}

As marcas tatuadas pelos tangomaos representam práticas relacionadas ao uso do corpo como um veículo de comunicação. Os registros corporais tinham como propósito identificar esses indivíduos como membros das sociedades locais, expressando visualmente que eles compreendiam suas linguagens e seus códigos.

Aventureiros, cristãos-novos, ou degredados, os tangomaos viam no negócio negreiro uma possibilidade rentável de negócio, passando a adotar as colônias africanas como moradia, onde poderiam deixar de lado seus estigmas marginalizados e se integrar de uma forma ativa na economia e na vida social local.

Essas variações na nomenclatura do séquito sinalizam para questões referentes as diferentes traduções das variantes de línguas do tronco linguístico banto, ao mesmo tempo nos permitem hipoteticamente questionar a variação de cargos, e de suas denominações, no governo de diferentes Ngolas. Beatrix Heintze ${ }^{24}$ em sua coletânea de artigos sobre Angola no século XVII dedica cinco capítulos introdutórios para a discussão de possibilidades metodológicas, e da importância da crítica de fontes utilizadas nas pesquisas sobre Angola colonial. Discute pontos relevantes como a produção de fontes ser em sua maioria produto da visão europeia, e da utilização de registros extraídos da tradição oral dos povos mbundus. A historiadora defende a utilização cuidadosa e o confronto de fontes para a aquisição e utilização de informações seguras.

Seguindo algumas dessas sugestões metodológicas, traçando paralelos cuidadosos, podemos concluir que a sociedade do Ndongo possuía um vasto séquito dedicado aos serviços do Ngola, funcionários estes que muitas vezes representavam a autoridade real desempenhando importantes funções nas etapas africanas do tráfico negro, principalmente nas negociações que intermediavam o contato entre as lideranças mbundus e os agentes responsáveis pela aquisição dos negros no interior dos reinos da África Centro Ocidental.

23 Palavras do cronista J. Tavares, citado por Luiz Felipe de Alencastro em seu livro O Trato dos viventes : Formação do Brasil no Atlântico Sul. São Paulo: Companhia das Letras, 2000, p. 48.

${ }^{24}$ HEINTZE, Beatrix. Op. cit. 


\title{
1.3. Nos bastidores do tráfico: acordos e barganhas na busca pelas peças da india
}

As trocas de mercadorias por corpos marcaram as primeiras etapas do tráfico. Desse ponto podemos discutir as transformações ocorridas nas sociedades mbundus após a abertura do mercado atlântico. Um item significativo foi a introdução de novos valores materiais entre essas comunidades.

Entre os gêneros mais apreciados pelos agentes africanos do tráfico estavam objetos de estanho, objetos de cobre, espelhos, miçangas, armas, munições, rolos de tabaco e tecidos. Segundo Pierre Chaunu: "Certas culturas africanas pagaram o luxo dos panos de cor que a sua indústria não sabia produzir, mas que o gosto desejaria, pelo preço elevado duma exportação de homens" 25 .

A cachaça também era muito apreciada, mas normalmente ela era fornecida aos intermediários como cortesia, não sendo usada na troca por escravos. Todos os negócios tinham como medida de equivalência a referência de uma pẹa, e as suas frações que eram as meias-peças e as braças, que equivaliam a um quarto da peça.

O termo peça da india, por sua vez, valia várias peças. A definição, negro peça da índia, era a representação em mercadorias do que se considerava como valor máximo de um escravo, podendo ser também convertido de acordo com o gênero e, ou a idade dos cativos. O significado desse termo vem sido trabalhado pela historiografia. Na definição de Regine Pernoud ${ }^{26}$ o termo negro peça da india era um africano entre 15 e 35 anos sem defeitos físicos e de boa constituição. Já para Roy Glasgow a definição é aplicada ao "escravo de primeira [...] entre os 18 e os 24 anos de idade, com cerca de seis pés (mais ou menos) de altura e sem nenhum defeito físico" 27 .

Affonse d'Escragnolle Taunay relaciona o uso dessa expressão ao hábito de se empilharem os escravos da mesma forma que os tecidos indianos, em suas palavras:

\begin{abstract}
arrumando a mercadoria humana como se tratasse de fardos, a empilhar as suas vítimas de tal modo que ainda lhes sobraria espaço para os clandestinos escapos dos rigores da taxa de exportação. [...] Assim ao nosso ver o nome peça da Índia originou-se de uma comparação de valores entre escravos e peças de pano de procedência indiana ${ }^{28}$.
\end{abstract}

\footnotetext{
${ }^{25}$ CHAUNU, Pierre. A civilização da Europa das Lužes. Lisboa: Ed. Estampa, 1985, vol. II, p. 48.

26 Gilberto Ferrez escreve que para Regine Pernoud, uma pesquisadora que analisou anteriormente o documento buscando uma identificação de seu autor, o termo negro peça da india era um africano entre 15 e 35 anos sem defeitos físicos e de boa constituição. FERREZ, Gilberto (org). "Diário...". Op. cit.

27 GLASGOW, Roy. Nžinga. Resistência africana ao colonialismo português em Angola. São Paulo: Ed. Perspectiva, 1982, p. 54.

28 TAUNAY, Affonso de Escragnolle. Subsídios para a História do tráfico africano no Brasil Colonial. Rio de Janeiro: Imp. Nacional, 1941, p. 589.
} 
No reino de Cabinda, localizado nos arredores das possessões portuguesas de Angola, um escravo peça da índia valia, em média, dez peças e uma braça; enquanto uma escrava peça da índia valia, também em média, oito peças e uma braça; já as crianças escravas, independente do sexo, valiam em torno de seis a sete peças e uma braça ${ }^{29}$. Uma peça podia ser negociada por determinados objetos, como por exemplo, dez bacias de cobre, ou por seis canecas pequenas de estanho, ou por vinte e quatro facas, mas nem todos os produtos poderiam ser usados no escambo, quando o africano que estivesse sendo negociado era uma peça da índia, nesse caso somente os itens mais desejados entravam nas transações ${ }^{30}$. Essas eram cotações dos mercados negreiros que variavam de acordo com os traficantes, fornecedores e futuros senhores.

Como salientou Marina de Mello e Souza:

O comércio com os portugueses e as mercadorias que introduzia forneciam novos e abundantes signos de prestígio. Dessa forma, os chefes envolvidos no tráfico, principalmente de escravos, tornavam-se mais poderosos e expandiam seus territórios e aldeias tributárias. Essas expansões davam-se por meio de guerras que mediam o poder dos chefes, estabeleciam novas composições políticas e territoriais e produziam escravos, disputados pelos mercados interno e externo, com um gradual predomínio deste ${ }^{31}$.

Partindo desses acordos comerciais várias redes foram formadas, em muitos casos aproximando as duas margens do Atlântico português e permitindo que grupos particulares realizassem seus negócios à margem da fiscalização metropolitana. Essas alianças exigiram dos colonizadores estratégias cuidadosas, onde o embate direto, conflitos físicos e as guerras, não deveriam ser os principais recursos para viabilizar os negócios, mas que foram mais constantes do que os discursos da Coroa idealizavam.

\section{$2^{\mathrm{a}}$ parte: $\mathrm{O}$ Ndongo e as disputas internacionais}

\subsection{Quem manda? Quem obedece? Interesses e projetos múltiplos para a administração do reino do Ndongo}

"O Portugal dos Filipes não se tinha construído sobre a residência do rei, mas sim sobre uma ausência" (Bouza Álvarez)

\footnotetext{
${ }^{29}$ As braças entram no preço dos escravos como taxa dada aos intermediários que cotavam esses valores. Cf. FERREZ, Gilberto. "Diário anônimo...". Op. cit.

${ }^{30}$ De acordo com o relato do viajante anônimo os intermediários, pumbeiros e tangomaos, determinavam quais eram os produtos que iriam ser trocados, e que deveriam ser envolvidos em cada etapa no máximo dois itens. Idem.

31 SOUZA, Marina de Mello e. Reis negros no Brasil escravista. História, mito e identidade na festa de coroação de rei congo. Belo Horizonte: Ed. UFMG, 2002.
} 
A afirmação de Bouza Álvarez pode ser ampliada também para questões relacionadas à administração colonial. Partindo dela podemos pontuar tanto a existência de dificuldades na afirmação da soberania portuguesa tanto junto aos mbundus, quanto aos estrangeiros que cobiçavam o lucrativo mercado atlântico de escravos.

Durante o período da União Ibérica (1580-1640) as possessões coloniais portuguesas foram governadas pelo Conselho de Portugal - instituição sediada em Madri, que posteriormente teve suas atribuições transferidas para o Conselho Ultramarino.

Nesse período a política filipina discursava sobre a importância das atividades missionárias junto às almas pagãs dos africanos, e defendia o estabelecimento de contatos pacíficos com as autoridades africanas. Nas entrelinhas dessas intenções identificamos nos ideais evangelizadores do resgate uma excelente oportunidade para a obtenção de escravos destinados aos mercados atlânticos. Os tratados teológicos procuraram durante todo o período escravista justificar e normatizar a captação e o cativeiro africano ${ }^{32}$.

Logo após a Restauração portuguesa, no ano de 1642, foi criado o Conselho Ultramarino $^{33}$, importante instituição responsável pela condução da administração colonial, com meta de normatizar as ações e nortear a condução dos negócios ultramarinos portugueses. Interpretamos a criação do Conselho Ultramarino como um reflexo da política portuguesa restaurada pela Casa de Bragança com pretensões de reafirmar sua soberania nos territórios coloniais.

O período posterior à Restauração representou uma virada determinante no que diz respeito à ocupação dos territórios da África Centro Ocidental. A Coroa portuguesa, agora sobre o governo de Dom João IV, tinha pela frente três desafios principais no que diz respeito ao reino do Ndongo. O primeiro objetivo era restabelecer a soberania nos territórios coloniais, após sessenta anos da administração filipina, o segundo era impedir a perda desses territórios para estrangeiros interessados no negócio negreiro, o que enfraqueceria consequentemente a economia da América portuguesa, e o terceiro objetivo era a implementação de uma bem sucedida política junto às autoridades dos mbundus.

\footnotetext{
32 Entre os principais tratados teológicos destacamos a obra de Manuel Ribeiro da Rocha, e suas definições sobre o que viria a ser o resgate humanitário. Ethíope resgatado... Lisboa: Of. patriarcal de Francisco Luiz Amaro, 1758. Jorge Benci e os ensinamentos sobre as metodologias cristãs para o castigo de escravos em $A$ economia cristã dos senhores no governo dos escravos. São Paulo: Ed. Grijalbo, 1977. E o sermão do padre Antônio Vieira sobre a condição escrava dos corpos cativos e a conquista da liberdade de suas almas. VIEIRA, padre Antônio. Maria Rosa Mystica. Excellências poderes e maravilhas do seu Rosário. Compendidas em trinta sermões ascéticos e panagyricos sobre os dois Evangelhos desta Solenidade, Novo e Antigo. Lisboa: Imp. Craesbeckiana, 1688.

$33 \mathrm{O}$ Conselho Ultramarino assumia as antigas funções do Conselho das Índias das Conquistas Ultramarinas, de acordo com Maria de Fátima Gouvêa a retirada do termo Índias representou o crescimento das colônias atlânticas em detrimento das possessões asiáticas. GOUVÊA, Maria de Fátima. Op. cit.
} 
Um importante embate, que teve como cenário o reino do Ndongo, em meados do século XVII, foi promovido pelas diferenças entre os jesuítas portugueses e os capuchinhos italianos. No ano de 1622, o papa Gregório XV criou a Propaganda Fide, instituição que defendia o fim do exclusivismo português nas atividades missionárias. Eram favoráveis à abertura dos trabalhos de evangelização para outras ordens religiosas, contrariando dessa forma os interesses da Companhia de Jesus. Esse conflito evidenciava os atritos entre a Coroa portuguesa e o Vaticano, e teve desdobramentos decisivos para história da África Centro Ocidental, evidenciando as alianças entre os poderes locais e os membros religiosos, muitas vezes defensores dos interesses de seus países.

Um dos casos mais relevantes foi a disputa entre esses grupos pela conversão da rainha Nzinga ${ }^{34}$, personagem célebre e polêmica citada e debatida pelos mais variados autores. A história da "cruel rainha" extrapola a questão da evangelização e fornece também uma perspectiva para os estudos sobre as alianças e as disputas de poder envolvendo portugueses, holandeses, jagas e mbundus na segunda metade do século XVII.

Nzinga reivindicava o trono do Ndongo, de acordo com seus argumentos ela seria a legítima herdeira do reino por ser a neta de um antigo soberano da região chamado Chiluangi Chiamdambi Angola (Kiluanj Kia Ndambi a Ngola). Os portugueses não viam com bons olhos essa pretensão de Nzinga, em função de seu temperamento difícil e de seus hábitos "jagas". Travaram com ela muitas batalhas, que marcaram o mandato de alguns governadores, como por exemplo, a administração de João Correia de Sousa, de Fernão de Sousa, Bartolomeu Vasconcelos da Cunha e Luís Mendes Chichorro.

Nesse contexto, as instruções da Coroa portuguesa, repassada e endossada pelos governadores, visavam à coroação de um Ngola aliado dos portugueses. Esse projeto foi finalmente bem sucedido no ano de 1626, com a coroação de Ngola Ari, rei do Ndongo, que durante toda a sua vida foi leal aos interesses dos portugueses. Ngola Ari forneceu apoio militar aos portugueses em uma batalha que isolou Nzinga e a levou às terras de Matamba, onde conseguiu junto aos jagas ter sua soberania reconhecida. Dessa forma assumiu o posto de rainha de Matamba.

No ano de 1621, Nzinga foi convertida ao catolicismo pelos portugueses passando a ser chamada Ana de Sousa, conversão extremamente política, que em momento algum significou uma real adoção dos princípios cristãos. Fato esse comprovado pela negação dos

\footnotetext{
${ }^{34}$ Muitos autores escreveram sobre Nzinga. Charles Ralph Boxer foi um dos primeiros estudiosos a dedicar atenção aos poderes africanos, principalmente no capítulo "Angola, a mãe preta", de seu livro Salvador Correia de Sá e a luta pelo Brasil e Angola. Outros autores também pesquisaram a trajetória de Nzinga, como Roy Glasgow e Luiz Felipe de Alencastro que, em seu já citado O Trato dos Viventes, analisa as referências à rainha em textos de Hegel e do Marquês de Sade.
} 
princípios religiosos, de acordo com relatos de missionários da época, Nzinga "transforma o reino de Matamba em um reino de luxúria e de perversidades" ${ }^{35}$. Posteriormente Nzinga volta a se converter, sendo que dessa vez sob a tutela dos capuchinhos italianos, gerando um profundo descontentamento entre os portugueses, sinalizando mais uma vez a utilização da possibilidade de conversão como fator para obter vantagens com os colonos estabelecidos nos territórios da África Centro Ocidental.

A luta contra as investidas de Nzinga eram pautas recorrentes na correspondência entre os administradores e a Coroa portuguesa. Entre vários embates uma de suas irmãs foi feita prisioneira pelos portugueses, o que serviu como elemento de barganha para várias tentativas de acordo.

\subsection{As vésperas da ocupação holandesa}

No ano de 1641, os holandeses tomaram Angola do controle da Coroa portuguesa. O mérito por esse feito foi creditado à recém fundada Companhia das Índias Ocidentais (WIC), uma instituição definida por Luiz Felipe de Alencastro como semi-privada que atuava no cenário internacional, conquistando territórios e dominando áreas estratégicas para a aquisição de escravos, fortalecendo dessa forma a presença política e os interesses econômicos dos holandeses nos territórios coloniais das duas margens do Atlântico. ${ }^{36}$

Ainda no período da União Ibérica, Espanha e Holanda assinaram um acordo que pretendia uma trégua entre esses países pelo período de doze anos. A dita Trégua dos Doze anos vigorou entre 1609 e 1621, não coincidentemente ano de criação da WIC. O fim dessa trégua reaviva hostilidades hispano-holandesas e altera o acesso dos Estados Gerais às mercadorias coloniais, desagradando e atrapalhando as ambições holandesas. Esse fator no contexto das disputas europeias foi decisivo para a realidade colonial nesse período. A partir desse período os holandeses passam a investir nos domínios coloniais, investindo principalmente nas colônias nordestinas da América portuguesa e nos territórios angolanos.

Os holandeses, mesmo sem a vivência portuguesa secular nas colônias, tinham claras suas metas de conquistar as duas margens atlânticas para a efetivação de um modelo sistêmico de exploração agrícola: ocupação territorial e fornecimento de escravos.

Em 1624, durante o governo de Fernão de Sousa, os holandeses conseguem estabelecer um bloqueio naval nas regiões de Benguela e Luanda, além de conquistar por um curto período regiões da Bahia, que foi recuperada no mesmo ano. As tropas do

\footnotetext{
35 ALENCASTRO, Luiz Felipe de. Op. cit., p. 278.

36 A Companhia das Índias Ocidentais foi fundada no ano de 1621, no contexto de ampliação dos investimentos neerlandeses nas atividades coloniais do Atlântico português. ALENCASTRO, Luiz Felipe de. Op cit.
} 
governador Fernão de Sousa evitaram o desembarque dos holandeses nos territórios angolanos, sinalizando para a Coroa a necessidade de fortalecer as defesas nesses limites da costa africana. O episódio evidencia as pretensões dos holandeses, e as dificuldades dos portugueses para a manutenção de seus domínios.

No ano de 1635, os holandeses conquistam a Zona da Mata pernambucana, e no ano seguinte Maurício de Nassau é nomeado governador da Nova Holanda ${ }^{37}$. Em 1641, tomam os territórios de Angola, enfraquecendo muito a posição portuguesa na região, que ficou praticamente reduzida as terras de Massangano.

A política implementada pelos holandeses em Angola nos leva a uma discussão conceitual sobre o modelo de governo indireto utilizado por Luiz Felipe de Alencastro para definir a relação entre portugueses e as autoridades locais. O autor identifica que a prioridade dos portugueses era o estabelecimento de acordos que visavam à cooperação, evitando ao máximo guerras, vistas como reveses ao bom andamento dos negócios negreiros na região.Comparando o pragmatismo dessas ações consideramos que esse conceito se aplica muito mais aos métodos de governo utilizados pelos holandeses, do que de fato pelos portugueses.

Analisando fontes do período, Beatrix Heintze ${ }^{38}$ fornece importantes sugestões metodológicas para a leitura e interpretação de discursos seiscentistas. Percebemos que muitos sobas de territórios adjacentes aos territórios de Luanda consideravam a presença holandesa como uma alternativa em contraponto com a presença portuguesa. Nesse mesmo recorte o então rei do Congo, Garcia II, escreveu para Maurício de Nassau disponibilizando fortalezas e outras facilidades comerciais. Afirmava que estava desiludido com os perversos e ambiciosos portugueses, que "tinham planejado conquistar o seu reino embaixo da capa da amizade" ${ }^{39}$.

Apesar das críticas aos portugueses, Dom Garcia deixava claro que permaneceria católico e que não aceitaria missionários, embaixadores ou colonos em seu reino. A força do catolicismo congolês superava as alterações políticas nos territórios da África Centro Ocidental $^{40}$. A marca do catolicismo no Congo é um importante fator desencadeador de embates entre os inacianos portugueses e os missionários capuchinhos italianos.

\footnotetext{
${ }^{37}$ Luiz Felipe de Alencastro cita o termo statthalter para o cargo assumido por Maurício de Nassau no governo dos territórios dominados. Idem.

${ }^{38}$ HEINTZE, Beatrix. Op cit.

${ }^{39}$ Correspondência do rei do Congo Garcia II, citada por BIRMINGHAM, David. Op cit., p. 120.

40 Marina de Mello e Souza analisa essa questão com profundidade em seu já citado Reis negros no Brasil escravista.
} 
Outro ponto desfavorável para os lusitanos nesse contexto, mas que não chega a ser surpreendente, foi a aliança entre os holandeses e a rainha Nzinga, que via nessa conquista a possibilidade de obter vantagens comerciais e principalmente para enfraquecer o rei do Ndongo, Ngola Ari, vassalo dos portugueses.

De acordo com a interpretação de Birmingham, os holandeses se aproximaram muito mais do modelo de administração indireta, firmando acordos de cooperação com as autoridades africanas, estabelecendo as bases conceituais do governo indireto. Partindo da noção de que para obter escravos não era necessário a implementação de um domínio dos grupos locais, nem mesmo gastos com conquistas militares. Preocupação recorrente entre os governadores portugueses que objetivavam o domínio do Ndongo. A articulação valeria mais do que a força na lógica dos holandeses, que poupavam seus esforços para os embates com os portugueses.

No ambiente restaurador posterior a 1640 , mesmo com as metas portuguesas para reaver a sua soberania em seus domínios ultramarinos, a presença holandesa além de enfraquecer os vínculos econômicos entre metrópole e colônias, representou um obstáculo ao reconhecimento da legitimidade da Casa de Bragança.

Vale ressaltar que a análise desses discursos de africanos que defendiam as investidas holandesas deve ser cautelosa, visto que podemos considerar que essa aparente preferência para negociar com os holandeses esteja relacionada ao fato de estarem em uma posição privilegiada naquele momento. A cordialidade em relação aos neerlandeses, evidenciada pelas críticas aos portugueses, pode ser considerada uma manobra para obter sua simpatia.

Por volta de 1646 o foco de resistência estava concentrado nos arredores de Massangano, o que preocupava os holandeses. A situação dos portugueses em Angola foi revertida com a chegada de Salvador Correia de Sá, que expulsou os holandeses inaugurando uma nova fase na administração de Angola, marcada pela governança de homens extremamente vinculados aos seus interesses particulares enraizados principalmente na América portuguesa. Uma das primeiras medidas tomadas por Salvador Correia de Sá foi a punição dos sobas que haviam se aliado aos holandeses.

O historiador Charles Boxer, em sua obra Salvador Correia de Sá, analisa a trajetória que levou o governador a enraizar interesses em variadas regiões do Império Ultramarino. Das atividades familiares tradicionais exercidas no Rio de Janeiro, passando pelos investimentos nas minas de prata de Potosí, chegando aos interesses escravistas nos 
territórios angolanos, Salvador Correia de Sá é um caso típico da terceirização dos sistemas de defesa da Coroa portuguesa para as mãos de particulares.

Além de todos os detalhes e da riqueza de fontes trabalhadas, Boxer inova trazendo para o debate o papel dos africanos como peças fundamentais para o desencadeamento da ocupação e posterior expulsão dos holandeses de Angola. Analisa o caso da conversão da rainha Nzinga, discute a organização dos sobados e oferece pistas para a compreensão da complexa hierarquia dos povos mbundus do Ndongo.

\section{$3^{a}$ parte: Angola brasílica: os governos de Salvador Correia de Sá, André Vidal de Negreiros e João Fernandes}

\subsection{Identidades brasilicas nos governos portugueses em Angola}

O período posterior a expulsão dos holandeses é caracterizado como um período de intensificação das guerras e de aumento nas tensões entre os governadores portugueses e as autoridades locais.

A administração de Salvador Correia de Sá marca um período de crescimento na exportação de escravos. Apesar da assinatura de um Tratado de Paz com o rei Garcia II do Congo, foram travadas batalhas com esse reino visando aumentar a influência da Coroa portuguesa em territórios adjacentes, conflitos esses que culminaram na guerra entre a Luanda portuguesa e o Congo.

Todos os investimentos de Salvador Correia de Sá eram coerentes com seu projeto de acumular riquezas particulares, ao mesmo tempo em que defendia os interesses da metrópole portuguesa. Ele e a geração que o sucedeu, definidos por Luiz Felipe de Alencastro como "governadores brasílicos", estiveram envolvidos nas lutas pela expulsão e pela defesa dos territórios da América portuguesa, o que os levava a crer que eram merecedores de privilégios que deveriam ser extraídos nas oportunidades geradas pela concessão de cargos administrativos em variados territórios do Império Ultramarino Português.

Essas redes de privilégios, típicas das sociedades do Antigo Regime, foram analisadas por Antônio Manuel Hespanha ${ }^{41}$. Em seus trabalhos Hespanha relaciona aspectos da administração colonial com as teias de relações, parentescos e recompensas que

\footnotetext{
41 XAVIER, Ângela B. \& HESPANHA, António M. "A Representação da Sociedade e do Poder". In: MATTOSO, José (dir.). História de Portugal, volume 4: O Antigo Regime. Lisboa: Editorial Estampa, 1993.
} 
muitas vezes determinaram a configuração dos quadros burocráticos das possessões ultramarinas.

O sucessor de Salvador Correia de Sá foi Rodrigo Miranda Henriques, que governou Angola de 1652 a 1653. Destacamos como metas de sua administração o plano de reabrir a carreira comercial: Luanda - Rio de Janeiro - Buenos Aires. Evidenciando a importância de Angola para os negócios comerciais lisboetas e fluminenses na bacia do Prata, projeto que foi uma das prioridades de Salvador Correia de Sá. ${ }^{42}$

Rodrigo Henriques chegou à Luanda com instruções para incrementar o comércio e cobrar o antigo tributo anual de escravos, que todos os chefes mbundus submetidos tinham sido anteriormente obrigados a pagar à Coroa Portuguesa. Morreu um ano após a sua chegada, segundo David Birmingham ${ }^{43}$, realizando poucas tarefas.

$\mathrm{Na}$ sequência da administração portuguesa em Angola, assumiu o governo Bartolomeu Vasconcelos da Cunha, em um período marcado pelos conflitos com a rainha Nzinga. Foi contrário às reivindicações de Nzinga em relação ao trono do Ndongo, e visando facilidades no acesso ao interior do Ndongo, barganhou a rendição de sua irmã Mukambu (Bárbara), prisioneira portuguesa. Exigia em troca da libertação facilidades para abrir uma rota comercial em direção à Matamba - território dominado pelos jagas, vassalos de Nzinga.

A origem e a composição do que chamamos de jagas é alvo de várias discussões entre os africanistas. Para Beatrix Heintze os termos jagas e imbangalas são sinônimos, já para David Birmingham os imbangalas são os componentes majoritários entre os acampamentos jagas. Em nossa pesquisa seguimos a definição de Birmingham em função da análise sobre o comportamento jaga de agregar em seus exércitos homens adultos de origens variadas.

Dando sequência à governança brasílica, desembarcou em Luanda Luís Mendes de Sousa Chichorro, que governou no período de 1654 a1658. Uma das principais singularidades de sua administração foi a aliança com os rebeldes jagas. Os jagas eram um grupo multi-étnico, de maioria imbangala, formado por homens que viviam de atividades relacionadas à guerra. Seus hábitos violentos eram sinônimos de ameaças entre os reinos e sobados da África Centro Ocidental.

Chichorro deu continuidade ao projeto de seu antecessor que pretendia estabelecer negociações com Nzinga. Apesar de ter recebido ordens expressas do rei Afonso VI para

\footnotetext{
${ }^{42}$ Uma das consequências desse movimento foi o avanço dos representantes da Coroa portuguesa em direção ao litoral sul, que posteriormente resultou na fundação da Colônia de Sacramento. Cf. BOXER, Charles Ralph. Op. cit.

${ }^{43}$ BIRMINGHAM, David. Op cit.
} 
não declarar nenhuma guerra, com exceção de um "motivo forte", originado por alguma atividade delituosa, tal como a implicação com comerciantes ou missionários, seu governo não fugiu a tendência brasílica de enxergar na guerra um método seguro para a efetivação de seus projetos.

Entre os feitos de Chichorro citamos as campanhas militares que pretendiam tornar os sobas de Quissama vassalos portugueses. A respeito dessa questão, a Câmara Municipal de Luanda foi contrária aos feitos do governador, temendo que Luanda ficasse desprotegida e vulnerável a um possível ataque holandês. Após um ano e meio em campanha, Chichorro resolveu regressar e concentrar seus esforços nas fronteiras de Angola e do Congo. Durante o governo de Sousa Chichorro, as tensas relações entre o Congo e Luanda resultaram em uma guerra intermitente, que persistiu por dez anos, até a batalha de Mbwila, em 1665, decretando o fracasso do Tratado de Paz assinado anos antes por Salvador Correia de Sá junto às autoridades congolesas.

João Fernandes Vieira, que governou Angola no período de 1658 a 1661, também encarava a nomeação para o cargo como uma recompensa pelos serviços prestados à Coroa Portuguesa na luta de reconquista de territórios da América Portuguesa contra os holandeses. Foi coerente com seus antecessores no que diz respeito ao uso de exércitos e da força, avesso ao modelo de um governo indireto, e mais próximo do que seria o fomento às rivalidades étnicas para aumentar o fornecimento de escravos para o mercado atlântico.

João Fernandes comandou três campanhas militares durante o seu mandato, provavelmente por altura das estações de seca. Joseph Miller ${ }^{44}$ defende em um de seus artigos a relação estabelecida entre as alterações nos fatores climáticos, prejudiciais à produção de alimentos nos territórios da África Centro Ocidental, ao aumento das fomes e das guerras.

A primeira foi um ataque em regiões próximas a Luanda, nos rios Bengo e Dande, contra um chefe local chamado Ngoleme a Kaita. Nesse ataque os portugueses contaram mais uma vez com o apoio de Ngola Ari. João Fernandes foi acusado mais tarde de ter destruído o chefado de Ngoleme a Kaita, súdito dos portugueses.

A segunda campanha militar de João Fernandes foi contra os Ndembus (Dembos), buscando evitar a fuga de escravos para terras do sul do Congo, de onde não podiam ser recuperados. A terceira campanha militar de João Fernandes foi contra os ovibumdus, em territórios ao sul, nas regiões do Libolo e Hako, enviou exércitos para proteger as rotas

${ }^{44}$ MILLER, Joseph. "The significance of drought, disease and famine in the agriculturally marginal zones of West-Central Africa”. In: The Journal of African History, vol. 3, nº1, p. 17-61. Cambridge University Press, 1982. 
comerciais na região garantindo o comércio de escravos e de marfim, já que a região estava sujeita a invasões dos imbangalas e de chefes libolos.

De acordo com Luiz Felipe de Alencastro, João Fernandes encetou preparativos militares para invadir o Congo logo que desembarcou em Luanda: “o Congo era perigoso não por suas capacidades ofensivas, mas porque constituía um pólo de atração antiescravista, acoitando escravos dos angolistas" ${ }^{45}$.

O governo de André Vidal de Negreiros (1661-1666) defendia a ação militar direta e o envio de seus homens de confiança ao interior para obter escravos pela força. No período de seu governo a guerra entre a Luanda portuguesa e o Congo, em 1665, assumiu seus contornos definitivos. Os portugueses alegavam que o rei do Congo, Dom Antônio I, se recusava a entregar as minas de ouro que haviam sido prometidas de acordo com o Tratado de Paz assinado por Salvador Correia de Sá e do rei do Congo, Garcia II. Negreiros levou as ofensivas de Chichorro e de João Fernandes às últimas consequências.

Após a morte de Ngola Ari I, rei do Ndongo e fiel vassalo dos portugueses, sucedeu no trono do Ndongo, Ngola Ari II. O novo rei colocou muitos obstáculos aos interesses da Coroa portuguesa. Essa resistência à presença portuguesa no Ndongo leva os colonizadores a organizarem uma reconquista, lutando contra Ngola Ari II, que foi derrotado, dando fim a realeza independente dos mbundus ocidentais.

\section{Conclusões:}

Após a Restauração, os territórios africanos dominados pelos portugueses foram palco de vários conflitos envolvendo interesses e motivações diversas.

A ameaça holandesa, e a sua efetiva ocupação, exigiram que os portugueses organizassem estratégias para minimizar os efeitos gerados pela aliança de alguns reis e de vários sobas que, nesse contexto, preferiram negociar com os agentes da WIC. A resistência nas terras de Massangano foi fundamental para a garantia das alianças com Ngola Ari, rei do Ndongo e fiel vassalo português, e para o contra ataque liderado por Salvador Correia de Sá, que deu início à um período de governos, que em suas ações destoaram, e muito, dos discursos da Coroa que pregavam a cooperação e o estabelecimento de alianças pacíficas com as lideranças africanas.

A ação de ordens missionárias religiosas fomentou outro foco de conflitos nos territórios do Congo e de Angola. Inacianos e capuchinhos refletiram na colonização do ultramar português divergências entre os direitos sobre a evangelização e sobre os métodos

\footnotetext{
${ }^{45}$ ALENCASTRO, Luiz Felipe de. Op cit, p. 285.
} 
para a condução dessa catequese-cativeiro, representando também um feixe dos conflitos entre o Vaticano e a Coroa portuguesa. O missionarismo como um dos braços da colonização estabeleceu sua marca na conversão, e principalmente na legitimação da prática escravista dos lusitanos, dos luso-africanos e mesmo entre os nativos convertidos, que viam no resgate das almas um bom negócio avalizado pela consciência dos feitos cristãos.

Em síntese, a pluralidade de grupos distintos fez com que o antigo reino do Ndongo fosse cenário de embates políticos, disputas por promissores negócios, ao mesmo tempo em que se tornava um lugar de intensas trocas culturais.

O recorte cronológico adotado engloba um período onde ameaças internas e externas foram simultâneas, e onde a própria hierarquia dos mbundus se refinava para atender às demandas das negociações, como, por exemplo, a especialização das funções de chefe de comércio, embaixadores e de vários componentes do séquito do Ngola.

A crescente abertura do mercado atlântico, e a busca pela afirmação da soberania portuguesa nos territórios mbundus alterou de forma significativa a realidade dos grupos africanos e exigiu das autoridades portuguesas uma versatilidade em seu sistema defensivo entre várias frentes distintas.

\section{Bibliografia:}

1. ALENCASTRO, Luiz Felipe de. O Trato dos Viventes. Formação do Brasil nos quadros do Atlântico Sul. São Paulo: Companhia das Letras, 2000.

2. BARRETO, Luiz Felipe. Os Descobrimentos e a ordem do saber - uma análise sóciocultural. Lisboa: Ed. Gradiva, 1989.

3. BIRMINGHAM, David. Alianças e conflitos. Os primórdios da ocupação estrangeira em Angola (1483-1750). Luanda: Arquivo Histórico de Angola, 2004.

4. BOXER, Charles Ralph. A Igreja e a expansão ibérica (1440-1770). Lisboa: Edições 70, 1989.

5. Salvador de Sá e a luta pelo Brasil e Angola (1602-1686). São Paulo: Ed. Nacional / EDUSP, 1973.

6. BOUZA ÁLVAREZ, Fernando. Portugal no tempo dos Filipes. Política, cultura, representações. (1580-1668). Lisboa: Edições Cosmos, 2000.

7. CHAUNU, Pierre. A civilização da Europa das Luzes. Lisboa: Ed. Estampa, 1985, vol. I. 
8. FRAGOSO, João; GOUVÊA, Maria de Fátima e BICALHO, Maria Fernanda (orgs.). O Antigo Regime nos trópicos: a dinâmica imperial portuguesa. Rio de Janeiro: Ed. Civilização Brasileira, 2001.

9. FRANÇA, Eduardo D’Oliveira. Portugal na época da restauração. São Paulo: Hucitec, 1997.

10. GLASGOW, Roy. Nžinga. Resistência africana ao colonialismo português em Angola. São Paulo: Ed. Perspectiva, 1982.

11. HEINTZE, Beatrix. Angola nos séculos XVI e XVII. Estudos sobre fontes, métodos e História. Luanda: Ministério da Cultura, 2007.

12. LOVEJOY, Paul E. A escravidão em Africa: uma história de suas transformações. Rio de Janeiro: Ed. Civilização Brasileira, 2000.

13. SOUZA, Marina de Mello e. Reis negros no Brasil escravista. História, mito e identidade na festa de coroação de rei congo. Belo Horizonte: Ed. UFMG, 2001.

14. TAUNAY, Affonse d'Escragnolle. Subsidios para a bistória do tráfico de africanos no Brasil Colonial. Rio de Janeiro: Imp. Nacional, 1941.

15. THORNTON, John. Africa and Africans in the making off Atlantic World, 1400-1680. Cambridge University Press, 1992.

16. ZERON, Carlos Alberto. "Pombeiros e Tangomaos, intermediários do tráfico de escravos na África - século XVI”. In: II Colóquio Internacional sobre mediadores culturais. Lagos: Centro de Estudos Gil Eanes, 1999, p. 15-38.

ARTIGO RECEBIDO EM: 20/05/2011

ACEITO PARA PUBLICAÇÃO EM: 24/06/2011 